\begin{tabular}{|c|l|}
\hline Title & $\begin{array}{l}\text { Effects of fire derived charcoal on soil properties and seedling regeneration in a recently burned Larix gmelinii Pinus } \\
\text { sylvestris forest }\end{array}$ \\
\hline Author(s) & $\begin{array}{l}\text { Kobay ashi, Makoto; Hirobe, Muneto; DeL uca, Thomas H.; Bryanin, Semyon V.; Procopchuk, V alentina F.; Koike, } \\
\text { Takay oshi }\end{array}$ \\
\hline Citation & $\begin{array}{l}\text { Journal of Soils and Sediments, 11(8), 1317-1322 } \\
\text { https://doi.org/10.1007/311368-011-04246 }\end{array}$ \\
\hline Issue Date & 2011-12 \\
\hline Doc URL & http://hdl.handle.net/2115/50761 \\
\hline Rights & The original publication is available at www.springerlink.com \\
\hline Type & article (author version) \\
\hline File Information & JSS11-8_1317-1322.pdf \\
\hline
\end{tabular}

Instructions for use 


\section{Effects of fire-derived charcoal on soil properties and seedling regeneration in a recently burned Larix gmelinii/Pinus sylvestris forest}

Makoto Kobayashi ${ }^{15}$, Hirobe Muneto ${ }^{2}$, DeLuca Thomas $\mathrm{H}^{3}$, Byrianin Semyon $\mathrm{V}^{4}$, Malashko, Evgenie $\mathrm{V}^{4}$, Procopchuk Valentina $\mathrm{F}^{4}$, Koike Takayoshi. ${ }^{{ }^{*}}$

${ }^{1}$ Lab. Silviculture and Forest Ecological Studies, Hokkaido University, Sapporo 060-8589, Japan

${ }^{2}$ Lab. Forest Ecology, Graduate School of Environmental Science, Okayama University, Okayama 700-8530, Japan

${ }^{3}$ SENRGY, Environment Centre Wales, Bangor University, Bangor, Gwynedd LL57 2UW, UK

${ }^{4}$ Lab. Agrochemistry and soil science, Far Eastern Agricultural University, Blagoveshchensk, 675009, Russia

${ }^{5}$ Climate Impact Research Center, Department of Ecology and Environmental Science, Umea University, Abisko, 981-07, Sweden

*corresponding author

Lab. Silviculture and Forest Ecological Studies, Hokkaido University, Sapporo 060-8589, Japan. Tel: (+81)-11-706-3854, fax: (+81)-11-706-2517,

Email address: tkoike@for.agr.hokudai.ac.jp 


\section{Abstract}

Purpose Fire is a primary form of disturbance in boreal ecosystem. Charcoal is an important byproduct of forest fire and has been reported to have the potential to influence the plant community establishing after fire. To date, however,, no study has effectively tested the relationship between charcoal and plant regeneration in the actual post-fire forests. To determine the contribution of charcoal to soil properties and plant regeneration after forest fires, we conducted in situ investigations concerning the relationship between charcoal and plant-soil system.

Materials and methods We conducted a field investigation in a recently burnt Gmelin larch (Larix gmelinii)/ Scots pine (Pinus sylvestris) forests in Russian Far East to investigate charcoal contents, $\mathrm{pH}$ water contents and nutrient availability in soil together with the regeneration of larch and pine seedlings.

Results and discussion Positive correlations were found between charcoal contents and soil $\mathrm{pH}$, water contents, and available P contents. Additionally, charcoal contents and number of pine seedlings were positively correlated. There was, however, no significant relationship between charcoal content and extractable $\mathrm{NH}_{4}{ }^{+}$content or the number of larch seedlings. These results suggest that while charcoal influences are somewhat obscure in the field, charcoal significantly contribute to the amelioration of water and nutrient availability together with the success of regeneration of pine seedling.

Conclusion Charcoal produced during fire events in Gmelin larch Scots pine forests of eastern Russia has a modest influence on soil properties, but has the potential to improve regeneration in these fire prone 
ecosystems.

Keywords forest fire, charcoal, phosphate, regeneration, Russian Far East 


\section{Introduction}

Fire is a natural disturbance that directly and indirectly influences the soil-plant system in boreal ecosystems (Kozlowski 1991; Goldammer and Fruaev 1996). In mixed conifer, broad-leaved forests of the Russian Far East, fire greatly affects plant regeneration (Goldammer and Furyaev, 1996; Makoto et al. 2007). Fire consumes the organic matter and releases $\mathrm{CO}$ and $\mathrm{CO}_{2}$ and generates charcoal as a result of incomplete combustion of biomass. Charcoal has been reported to have effects on plant and soil systems (e.g. Tryon 1948; Zackrisson et al. 1996; Wardle et al. 1998; Glaser et al. 2002; Lehmann et al. 2003; MacKenzie and DeLuca 2006; Warnock et al. 2007; DeLuca et al. 2009; Makoto et al. 2010, 2011). The physical structure of charcoal is highly porous (Preston and Schmidt 2006) providing a great deal of specific surface and the capacity to adsorb water, organic compounds and nutrients in soil (Glaser et al. 2002). As a result, the presence of charcoal in the rhizosphere often increases the plant productivity mainly through the increased availability of soluble and insoluble nutrients (e.g. Tryon 1948; Glaser et al. 2002; Lehmann et al. 2003; DeLuca and Sala 2006; Makoto et al. 2010). Based on these studies, it is thought that charcoal may be a major determinant of tree regeneration success in the post-fire forest ecosystem.

While the mechanisms mentioned above have often been investigated employing model experiments, few studies have been conducted to provide field evidence for the relationship between the presence of charcoal and its effects on soil properties and processes in the post-fire forest (MacKenzie et al. 2008). 
Furthermore, no study has been conducted to access the relationship between charcoal and tree regeneration in the natural setting of forest ecosystem where various factors confound plant behavior and charcoal effects. To determine the contribution of charcoal to soil properties and plant regeneration after forest fire, we conducted an in situ investigation concerning the relationship between charcoal and plant-soil system response. This study provides an enhanced understanding of how charcoal can influence ecosystem processes in fire prone boreal forests.

\section{Materials and Methods}

Site description

The field research was conducted in a forest, $40 \mathrm{~km}$ south of Zeya city, in the northern part of Amur

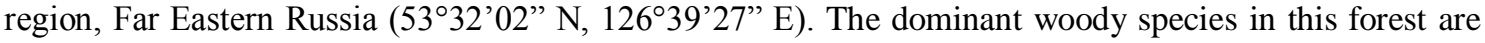
Gmelin larch (Larix gmelinii), mixed with Scots pine (Pinus sylvestris), white birch (Betula platyphylla), and Dahurian birch (Batula davurica) (Table 1). From disks taken from larch stems, the stand age was estimated about $120 \mathrm{yr}$ old. The soil type is brown taiga soil, and the soil texture is sandy loam formed from tertiary sedimentary rock. This area was the northern most part of the non-permafrost soil region, with a mean annual temperature of about $-2.1^{\circ} \mathrm{C}$ and a mean annual precipitation of about $520 \mathrm{~mm}$. The study area is relatively flat resulting in a consistent elevation across the plots (c.a. $300 \mathrm{~m}$ ). The fire season in this region extends from the end of April to the beginning of July and from the end of September to the 
end of October. Main type of the forest fire in this region is surface fire. The study site experienced a

surface fire in the fall of 2007. The intensity of the surface fire was such as to kill the mature birch trees, but not kill the mature larch and pine trees.

Study design and method of sampling and chemical analysis

We established a $1 \mathrm{~m}$ by $25 \mathrm{~m}$ belt-transect in the study site in the beginning of June 2009 .

Continuous microplots (measuring $50 \mathrm{~cm}$ by $50 \mathrm{~cm}$ ) were established along the belt resulting in a total of

100 plots Fig 1. In each microplot, we counted the number of larch and pine seedlings that were established since the 2007 fire. In the center of each plot, relative light intensity was about $20 \%$ of the open area as determined by using diazo sensitized paper (Opt leaf R3D, TAISEI E\&L, Japan) and sampled the substrate of forest floor beneath the litter layer (totaling 100 samples). After removing the litter layer, cores of $12.7 \mathrm{~cm}$ diameter and $5 \mathrm{~cm}$ depth (volume is $200 \mathrm{ml}$ ) was taken at each point, all 100 sample points were sampled in one day. Due to the variability in the depth of F-H horizon, the relative contents of organic and mineral matter varied by samples. The depth of sampling was chosen as to target the collection of substrate where the root system of the seedlings are primarily located as determined in preliminary studies. The samples were brought to the laboratory and immediately placed in a cold storage at $4^{\circ} \mathrm{C}$ until processed for analysis in the Far Eastern Agricultural University, in Blagoveshchensk, Amur region. 
Samples from each microplot was carefully mixed, and all gravel, roots, twigs and litter greater than $5 \mathrm{~mm}$ diameter were removed by sieving and hand sorting. Fresh soil samples were then extracted by shaking $10 \mathrm{~g}$ of soil with $100 \mathrm{ml}$ of $2 \mathrm{M} \mathrm{KCl}$ for $1 \mathrm{~h}$ before filtering through Whatman 2 filter paper. Extracts were then analyzed for $\mathrm{NH}_{4}{ }^{+}$by spectrophotometer using the indophenol blue absorptiometry method (KFH-2-UHL-4.2 ZAGORSKY, Russia) and $\mathrm{NO}_{3}{ }^{-}$in the extract was determined by using an ion selective electrode (ELISS-121, SCI PRIDCUTION ASSOC MEASUR TECH, Russia). Unfortunately, all $\mathrm{NO}_{3}{ }^{-}$analyses were below detection limits of the electrodes, therefore in this study, we do not present these results. Soil samples were also analyzed for available P content using the Bray II method (Kuo 1996). Contents of all nutrients converted to a dry mass basis by taking the water content of the fresh samples into account. Water content was determined by weighing about $20 \mathrm{~g}$ of fresh soil, drying for $18 \mathrm{~h}$ day at $60^{\circ} \mathrm{C}$ in a drying oven and then reweighing the sample after it had cooled. Soil acidity was determined by measuring the $\mathrm{pH}$ of a suspension of $10 \mathrm{~g}$ of fresh sample suspended in $100 \mathrm{ml}$ of deionized water (1:10 sample: $\left.\mathrm{H}_{2} \mathrm{O}\right)$. The suspension was shaken for $1 \mathrm{~h}$ before measurement on a compact pH meter (B-212, HORIBA, Japan).

\section{Analysis of charcoal content}

Oven-dried samples were used for the analysis of charcoal contents in organic layer and mineral soil.

Charcoal content was determined by using a modified version of the CT0375 method (Gustafsson et al. 
1997). The quantity of charcoal in soils was estimated as the difference in sample weight between the thermal treatment at $375^{\circ} \mathrm{C}$ and then at $450^{\circ} \mathrm{C}$. This method is based on the assumption that more than 99.85\% of all organic carbon, except for charcoal and soot, is volatilized at $375^{\circ} \mathrm{C}$ and less than $10 \%$ of black carbon remains after combustion at $450^{\circ} \mathrm{C}$ (Gustafsson et al. 1997). These two temperatures are those used in the chemo thermal method "CTO375 method" which analyzes the charcoal contents as the carbon contents reduced between the two temperatures by elemental analyzer.

The direct estimation of the charcoal amount in the sample based on the decreased weight can include the amount of black carbon other than charcoal and confuse the interpretation of the data. However, from the view point of that study site is $5 \mathrm{~km}$ from the road and the industrial area producing the black carbon as soot and aerosol, we believed that the most amount of black carbon identified in this method represents the amount of charcoal produced by forest fire. Although this method tends to underestimate the quantity of charcoal in soil (Schmidt et al., 2006) we believe that the method provided a reasonable estimation of charcoal added to the soil in recent fire events. The benefit of this method is that this method is that it could be conducted conveniently in our remote field location with only a balance, drying oven, and muffle furnace thus allowing for the rapid processing of many samples with decent reliability.

Briefly, samples were ground with mortar and pestle, and sieved to under $500 \mu \mathrm{m}$. A $0.5 \mathrm{~g}$ oven-dried soil sample was then placed in a thin layer in a $5 \times 10 \mathrm{~cm}$ aluminum tray. The sieving and thin placement 
of the sample were conducted to facilitate oxygenation and thus combustion of the organic matter in the soil samples and avoid production of charcoal during the analysis (Gustaffson et al. 2001; Schmidt et al. 2001). During the combustion in a muffle furnace, an excess amount of oxygen was directed into the muffle furnace (Gustafsson et al. 1997, 2001). The content of charcoal in the sample is then determined by difference between the mass of the $375^{\circ} \mathrm{C}$ sample and the $450^{\circ} \mathrm{C}$ sample after drying at $60^{\circ} \mathrm{C}$ for $18 \mathrm{~h}$. The summery of the charcoal content and other analyzed parameters were showed in the Table 2 .

\section{Statistical analysis}

Correlations between charcoal contents and all soil properties and number of seedling for each species were analyzed by generalized linear model (GLM). All soil properties were estimated to follow the Gaussian distribution. Numbers of seedlings for both species were estimated to follow the Poisson distribution. Correlation between two parameters was evaluated to be significant at $\mathrm{p}<0.05$. All statistical analyses were conducted using R software 2.9.0 (R developing core team 2009).

\section{Results}

We found significant positive correlations between charcoal content and soil $\mathrm{pH}$, soil water contents, and available P contents (Fig. 2). Furthermore, charcoal content and number of pine seedlings regenerated in a plot also has significantly positive correlation (Fig. 2). Interestingly, there was no significant correlation 
between charcoal content and extractable $\mathrm{NH}_{4}{ }^{+}$content or the number of larch seedlings (Fig. 2, p=0.664

and 0.5135 respectively).

\section{Discussion}

We provide, for the first time, field evidence for a positive relationship between charcoal content and number of pine seedlings and chemical properties of soil and forest floor (Fig. 2). There were, however, several parameters which were not influenced by charcoal, even though previous laboratory experiments would have predicted otherwise.

The positive correlation between charcoal contents and soil $\mathrm{pH}$ are likely due to the fact that fire oxidizes organic material concentrating alkaline oxides along with the charcoal (Tryon 1948; Glaser et al. 2002). The positive relationship between charcoal contents and soil water content is likely due to the porus nature of charcoal and its ability to hold the water (Keech et al. 2005). Charcoal is known to retain an enormous micro- and macro-porosity resulting in a great water holding capacity per unit mass of charcoal thereby enhancing the retention of water in the forest floor and mineral soil (Glaser et al. 2002). Higher available $\mathrm{P}$ contents in the presence of charcoal may be due to concentration of $\mathrm{P}$ in low temperature generation of charcoal (Gundale and DeLuca 2006) as might be expected in a low severity surface fire. Alternatively, P might combine with $\mathrm{Ca}$ and $\mathrm{Mg}$ in the macro-pores (Glaser et al. 2002) temporarily forming stable phosphate precipitates. Soil phosphate has low mobility (Ceritini 2005) and is 
likely to remain in the macro-pores of charcoal until organic acids slowly liberate soluble P. Thus, available P should have positive correlation between charcoal contents assuming low charcoal generation temperature and minimal fire induced volatilization of $\mathrm{P}$. It is likely that $\mathrm{Ca}-$ and $\mathrm{Mg}-\mathrm{P}$ precipitates can be extracted by Bray 2 method (Bray and Kurts 1945). This would also suggest that this source of P would be available for plants through the acidification of phosphate with organic acids exuded from roots, mycorrhiza, or P solublizing bacteria (Allen 1991, Finlay 2008).

There was no positive relationship between extractable soil $\mathrm{NH}_{4}{ }^{+}$and charcoal presence. In previous studies, $\mathrm{NH}_{4}{ }^{+}$absorption to man-made charcoal amendment to tropical soils has been implicated to result in reduced occurrence of $\mathrm{N}$ leaching from soil (Lehmann et al. 2002). However, it is likely that the direct adsorption of $\mathrm{NH}_{4}{ }^{+}$to charcoal would be specific to the type of charcoal in question. In fact it is implicated $\mathrm{NH}_{4}{ }^{+}$might be weakly adsorbed to charcoal (Berglund et al. 2004). The lack of detection of $\mathrm{NO}_{3}{ }^{-}$using the ion selective electrode precluded testing of the reported effect of charcoal on net nitrification in boreal and temperate coniferous forests (DeLuca et al. 2006). Further studies might be conducted, in the field, to elucidate how charcoal influences biological process of nitrification or net immobilization (DeLuca et al. 2006, 2009), both serving as pathways that might decrease the extractable soil $\mathrm{NH}_{4}^{+}$.

There was a positive relationship between charcoal contents and the number of pine seedlings. However no other single factor $\left(\mathrm{pH}, \mathrm{NH}_{4}\right.$, available $\mathrm{P}$ and water contents of soil) which can be related 
with the seedling emergence had any significant effects on the numbers of pine (data not shown).

Charcoal can affect plant emergence though the improvement of growth and seed germination (Choi et al.

2009; Makoto et al. 2010, 2011). Although we do not attain any conclusive data, this knowledge suggests

that charcoal increased $\mathrm{P}$ availability and water contents, and these two factors increased seedling emergence not independently but cooperatively. In the northeastern China, which is close to our site, the Pinus sylvestris forests were observed to be $\mathrm{P}$ and water limited for the tree growth (Zhao et al. 2009). Meanwhile, there was no relationship between soil charcoal content and the number of larch seedlings. From our field observation, one plausible explanation for such species specific effects might be due to that pine seedling shows faster growth and develop their root system more rapidly than those of larch seedling. Qu et al. (2009) reported that more dense root development, the more the positive effect of soil nutrients is observed attained exponentially. The positive effect of charcoal on the root system and growth of plants (e.g. amelioration of nutrient availability and moisture condition and sorption of phenolics as toxic matter) might be a result of greater root development and increased contact with charcoal in the forest floor. To verify this explanation, it would be necessary to investigate the mechanisms causing such species specific effects of charcoal on tree seedlings in intensive microplots or greenhouse studies. On the other hand, while we observed some significant relationships between charcoal and various parameters, there was a great deal of variation in the data (Fig. 2). This implicates that, in the field, fire-derived charcoal affect soil properties and seedling growth significantly as a factor among various ones which 
also affect them coincidentally.

These results reveal the in situ ecological significance of charcoal in boreal forest ecosystems in terms of both plant and soil response. Importantly, the spatial distribution of charcoal has been reported to influence the distribution of nutrient contents in the forest floor (MacKenzie et al. 2008). To be effectively assess the role of charcoal in the heterogeneous environment of the boreal ecosystem, ultimately we would need to evaluate the spatial relationship between the charcoal distribution, soil condition, and regeneration of seedlings taking their spatial heterogeneities into consideration.

\section{Acknowledgement:}

We thank Dr. F. Satoh, Dr. M. Shibuya and Dr. H. Saito for their valuable comments for this study. Thanks are also due to Dr. Y. P. Nemilostiv for his help throughout the research in the Russian Far East.

This study is supported in part by the Grant-in-Aid of JSPS to Hashidoko, Y. (type A 2025500208), that to K. Makoto (NO. 192105), that to Koike, T. (Type B 20380083).

\section{References:}

Allen MF (1991) The ecology of mycorrhiza. Cambridge University Press, Cambridge

Bray RH, Kurts LT (1945) Determination of total, organic and available forms of phosphorus in soils. Soil Sci 59:39-45

Certini G (2005) Effects of fire on properties of forest soil: a review. Oecologia 143:1-10

Choi DS, Makoto K, Quoreshi A, Qu L (2009) Seed germination and seedling physiology of Larix 13 
kaempferi and Pinus densiflora in seedbeds with charcoal and elevated $\mathrm{CO}_{2}$. Landscape Ecol Eng 5: $107-113$

DeLuca TH, MacKenzie MD, Gundale MJ (2009) Bio-char effects on soil nutrient transformation. In: Lehmann J, Joseph S (eds) Biochar for Environmental Management: Science and Technology. Earthscan Publications Ltd, London, pp 251-270

DeLuca TH, MacKenzie MD, Gundale MJ, Holben WE (2006) Wildfire-produced charcoal directly influences nitrogen cycling in ponderosa pine forests. Soil Sci Soc Am J 70:448-453

DeLuca TH, Sala A (2006) Frequent fire alters nitrogen transformations in ponderosa pine stands of the inland northwest. Ecology 87:2511-2522

Finlay RD (2008) Ecological aspects of mycorrhizal symbiosis: with special emphasis on the functional diversity of interactions involving the extraradical mycelium. J Exp Bot 59:1115-1126

Glaser B, Lehmann J, Zesh W (2002) Ameliorating physical and chemical properties of highly weathered soils in the tropics with charcoal-a review. Biol Fertil Soils 35:219-230

Goldammer JG, Furyaev VV (1996) Fire in Ecosystem of Boreal Eurasia. Kluwer Academic Publishers, London

Gundale MJ, DeLuca TH (2006) Temperature and source material influence the chemical properties of charcoal in the ponderosa pine/Douglas-fir ecosystem. For Ecol Manag 231:86-93

Gustafsson O, Haghseta F, Chan C, Macfarlane J, Gschwend PM (1997) Quantification of dilute sedimentary soot phase: implication for PAH speciation and bioavailability. Environ Sci Technol 31:203-209

Gustafsson O, Bucheli T, Kukulska Z, Andersson M, Claude L, Rouzaud JN, Reddy CM, Eglinton TI (2001) Evaluation of a protocol for the quantification of black carbon in sediments. Global Biogeochem Cy 15:881-890

Kozlowski TT, Kramer PJ, Pallardy SG (1991) The Physiological Ecology of Woody Plants. Academic Press, San Diego

Keech O, Carcaillet C, Nilsson MC (2005) Adsorption of allelopathic compounds by wood-derived charcoal: the role of wood porosity. Plant Soil 272:291-300

Kuo S (1996) Phosphorous. Methods of soil analysis. Part 3. $3^{\text {rd }}$ ed. SSSSA Book Series 5. SSSSA, Madison, Wisconsin 
Lehmann J, da Silva Jr JP, Steiner C, Nehls T, Zech W, Glaser B (2003) Nutrient availability and leaching in an archaeological Anthrosol and a Ferralsol of the central Amazon basin: fertilizer, manure and charcoal amendments: Plant Soil 249:343-357

MacKenzie MD, McIntire EJB, Quideau SA, Graham RC (2008) Charcoal Distribution Affects Carbon and Nitrogen Contents in Forest Soils of California. Soil Sci Soc Am J 72:1774-1785

MacKenzie MD, DeLuca TH (2006) Charcoal and shrubs modify soil processes in ponderosa pine forests of western Montana. Plant Soil 287:257-266

Makoto K, Nemilostiv YP, Zyryanova OA, Kajimoto T, Matsuura Y, Yoshida T, Satoh F, Sasa K, Koike T (2007) Regeneration after forest fires in mixed conifer broad-leaved forests of the Amur region of Far Eastern Russia: the relationship between species specific traits against fire and recent fire regimes. Eurasian J For Res 10:51-58

Makoto K, Tamai Y, Kim YS, Koike T (2010) Buried charcoal layer and ectomycorrhizae cooperatively promote the growth of Larix gmelinii seedlings. Plant Soil 327:143-152

Makoto K, Choi DS, Hashidoko Y, Koike T (2011) The growth of Larix gmelinii seedlings as affected by charcoal produced at two different temperatures. Biol Fertil Soils 47:467-472

Preston CM, Schmidt MWI (2006) Black (pyrogenic) carbon: a synthesis of current knowledge and uncertainties with special consideration of boreal zone. Biogeosci 3:397-420

Qu L, Quoreshim AM, Koike T (2003) Root growth characteristics, biomass and nutrient dynamics of seedlings of two larch species raised under different fertilization regimes. Plant Soil 255:293-302

Schmidt MWI, Skjemstad JO, Czimczik CI, Glaser B, Prentice KM, Gelinas Y, Kuhlbusch AJ (2001) Comparative analysis of black carbon in soils. Global Biogeochem Cy 15:163-167

Tryon EH (1948) Effect of charcoal on certain physical, chemical, and biological properties of forest soils. Ecol Monogr 18:82-115

Warnock DD, Lehmann J, Kuypern TW, Rilling MC (2007) Mycorrhizal response to charcoal in soil concepts and mechanisms. Plant Soil 300:9-20

Wardle DA, Zackrisson O, Nilson MC (1998) The charcoal effect in Boreal forests: mechanisms and ecological consequences. Oecologia 115:419-426

Zackrisson O, Nilsson MC, Wardle DA (1996) Key ecological function of charcoal from wildfire in the Boreal forest. Oikos 77:10-19 
Zhao Q, Liu X, Zeng D, Liu J, Hu Y (2009) Relationship between foliar phosphorous fractions of Pinus sylvestris var. mongolica and soil available phosphorous. Front For China 4:85-89 
Table 1 Overview of the stand structure in the study site.

\begin{tabular}{cccccc}
\hline & $\begin{array}{c}\text { Larix } \\
\text { gmelinii }\end{array}$ & $\begin{array}{c}\text { Pinus } \\
\text { sylvestris }\end{array}$ & $\begin{array}{c}\text { Betula } \\
\text { platyphylla }\end{array}$ & $\begin{array}{c}\text { Betula } \\
\text { davurica }\end{array}$ & Total \\
\hline Average DBH $(\mathrm{cm})$ & 18.7 & 19.7 & 20.6 & 23.9 & 20.7 \\
Basal area $\left(\mathrm{m}^{2} \mathrm{ha}^{-1}\right)$ & 28.9 & 1.0 & 8.1 & 1.4 & 39.4 \\
Density $($ individuals ha & & & \\
\hline
\end{tabular}


Table 2 Summary of the parameters investigated in the present study.

\begin{tabular}{|c|c|c|c|c|c|c|}
\hline & Min & Median & Mean & Max & SD & $\mathrm{CV}(\%)$ \\
\hline Charcoal (mg kg $\left.{ }^{-1}\right)$ & 0.0 & 8.0 & 8.3 & 25.4 & 4.5 & 54.1 \\
\hline $\mathrm{NH}_{4}-\mathrm{N}\left(\mathrm{mg} \mathrm{kg}^{-1}\right)$ & 0.5 & 5.3 & 6.4 & 21.3 & 3.5 & 55.5 \\
\hline Available P (mg kg $\left.{ }^{-1}\right)$ & 7.8 & 25.0 & 29.6 & 93.4 & 17.7 & 59.6 \\
\hline $\mathrm{pH}$ & 5.6 & 6.4 & 6.3 & 7.1 & 0.4 & 5.7 \\
\hline Water content $(\%)$ & 16.5 & 30.9 & 33.7 & 71.6 & 11.4 & 33.8 \\
\hline Larch seedling (trees plot ${ }^{-1}$ ) & 0.0 & 1.0 & 1.3 & 5.0 & 1.1 & 90.7 \\
\hline Pine seedling (trees plot $^{-1}$ ) & 0.0 & 1.0 & 1.5 & 6.0 & 1.4 & 97.6 \\
\hline
\end{tabular}




\section{Caption to Figures}

Figure 1 Experimental design for the soil sampling and count seedling number. Number of seedlings was counted in each $0.025 \mathrm{~m}^{2}$ microplot $(0.5 \mathrm{~m} * 0.5 \mathrm{~m})$. Sample of forest floor was collected from the center of each microplot.

Figure 2 Relationships between charcoal content and soil parameters and number of seedling. $\mathrm{NH}_{4}-\mathrm{N}$, Available $\mathrm{P}$, Water content and $\mathrm{pH}$ are the properties of forest floor. Pine seedling and Larch seedling are the number of seedling in a $50 \mathrm{~cm} * 50 \mathrm{~cm}$ plot. The significant relations analyzed by GLM were shown with $\mathrm{p}$ value and equation. Significant correlation was evaluated at $\mathrm{p}<0.05$. 
Figure 1

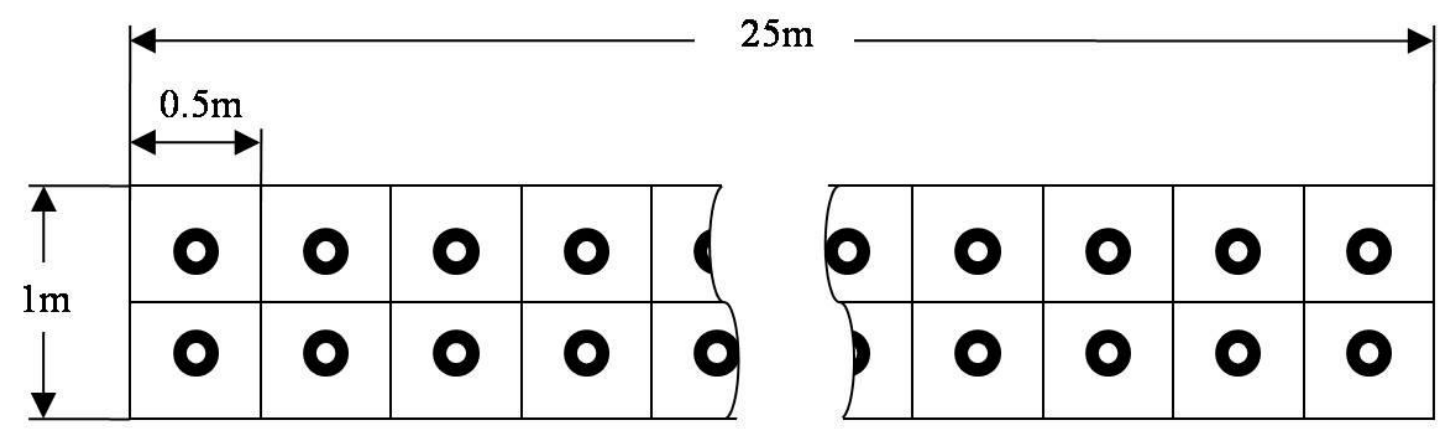


Figure 2
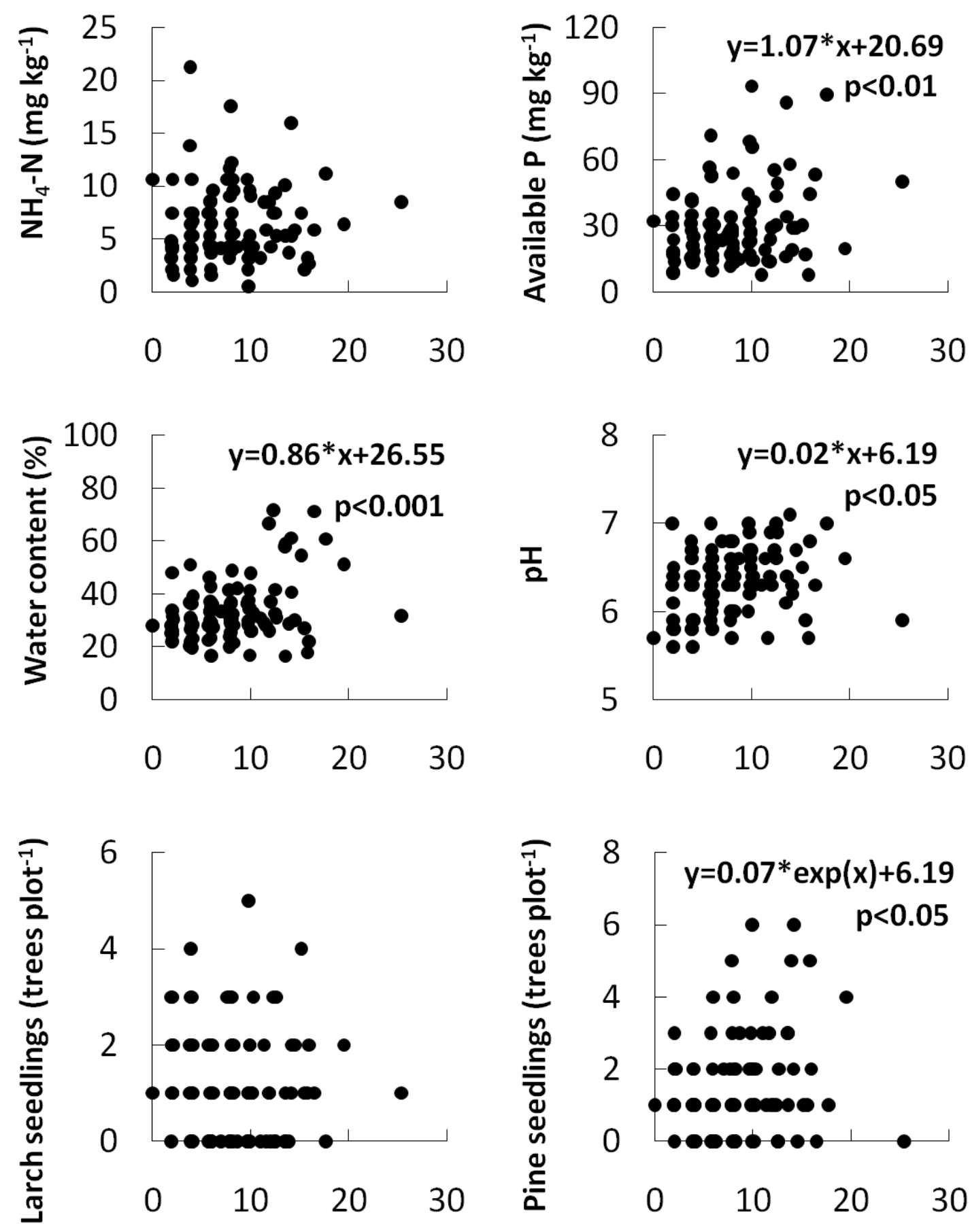

Charcoal content (mg kg-1) 